University at Buffalo School of Law

Digital Commons @ University at Buffalo School of Law

Journal Articles

Faculty Scholarship

Summer 2013

\title{
Towards Engaged Scholarship
}

John R. Nolon

Michelle Bryan Mudd

New York Law School

Michael Burger

Kim Diana Connolly

University at Buffalo School of Law

Nestor Davidson

See next page for additional authors

Follow this and additional works at: https://digitalcommons.law.buffalo.edu/journal_articles

Part of the Legal Education Commons, and the Legal Studies Commons

\section{Recommended Citation}

John R. Nolon, Michelle B. Mudd, Michael Burger, Kim D. Connolly, Nestor Davidson, Matthew Festa, Jill I. Gross, Lisa Heinzerling, Keith H. Hirokawa, Tim Iglesias, Patrick C. McGinley, Sean Nolon, Uma Outka, Jessica Owley, Kalyani Robbins, Jonathan Rosenbloom \& Christopher Serkin, Towards Engaged Scholarship, 33 Pace L. Rev. 821 (2013).

Available at: https://digitalcommons.law.buffalo.edu/journal_articles/193

\section{C) ${ }_{\text {COPYRIGHT }}^{\text {N }}$}

This Article is brought to you for free and open access by the Faculty Scholarship at Digital Commons @ University at Buffalo School of Law. It has been accepted for inclusion in Journal Articles by an authorized administrator of Digital Commons @ University at Buffalo School of Law. For more information, please contact lawscholar@buffalo.edu. 


\section{Authors}

John R. Nolon, Michelle Bryan Mudd, Michael Burger, Kim Diana Connolly, Nestor Davidson, Matthew

Festa, Jill I. Gross, Lisa Heinzerling, Keith H. Hirokawa, Tim Iglesias, Patrick C. McGinley, Sean Nolon, Uma

Outka, Jessica Owley, Kalyani Robbins, Jonathan Rosenbloom, and Christopher Serkin 


\title{
Towards Engaged Scholarship
}

\author{
John R. Nolon, ${ }^{*}$ Keith Hirokawa, and Sean Nolon
}

\section{Introduction and Background}

As teaching evolves to embrace the skills, values, and contexts of law practice, should scholarship become more engaged in the practice as well? Twenty years ago the American Bar Association's ("ABA") Task Force on Law Schools and the Profession: Narrowing the Gap, issued its report titled Legal Education and Professional Development: An Educational Continuum, also referred to as the MacCrate Report. ${ }^{1}$ A key finding of the report was that law schools were not doing an adequate job of instilling in future lawyers the types of professional skills and values necessary to the practice of law. Five years ago, two additional reports stepped up and sharpened this criticism of legal education: the Carnegie Foundation's Educating Lawyers in $2007^{2}$ and the report of the Clinical Legal Education Association ("CLEA"), titled Best

* Professor of Law and Counsel to the Land Use Law Center, Pace Law School; Visiting Professor, Yale School of Forestry and Environmental Studies. Professor Nolon served as the visionary, organizer, principal author, and a contributor in this successful collaboration. He initially launched this project through informal dialogue at conferences and professional events as a conversation that followed the May 2011 conference on Practically Grounded. See infra note 8 . All of the contributors immediately realized the transformative potential of Professor Nolon's proposal. The contributors are grateful for the opportunity to participate in this innovative and far-reaching project and thank Professor Nolon for spearheading the event and the publication. Professor Nolon did a tremendous job in bringing these folks together, facilitating a productive dialogue, developing the products of this collaboration, and capturing the themes and importance of the contributions as the principal author. The structure and tone of this article benefitted from the advice of Professor Nestor Davidson, Fordham University School of Law, and Professor Jill Gross, Director of Legal Skills at Pace Law School.

1. TASK Force on Law Schools and the Profession, AM. Bar Ass'n, Legal Education and Professional DeVelopment: AN Educational CONTINUUM (1992).

2. See William M. Sullivan, AnNe Colby, Judith Welch Wegner, Lloyd Bond \& Lee S. Shulman, Educating LaWyers: Preparation for the PROFESSION OF LAW 15 (2007) [hereinafter Educating Lawyers]. 
Practices for Legal Education. ${ }^{3}$ A key principle of legal education found in Best Practices is that law schools should commit to preparing students to practice law "effectively and responsibly in the contexts they are likely to encounter as new lawyers."4

These reports have stimulated a vast literature on how law professors can improve their teaching methods, how law schools can alter their curricula, and how the legal academy as a whole can prioritize skills education. ${ }^{5}$ Less attention has been paid, however, to the connection between legal scholarship and practice-oriented teaching. There is an intuitive link, for many law professors, between their teaching and scholarship. ${ }^{6}$ To improve our teaching of doctrine or theory, we need to conduct research in those realms and use our conclusions, expressed routinely in law review articles, to enhance our teaching. How can we teach law students to think like lawyers, to analyze cases, and to determine how judges decide disputes, if we do not write on these matters of doctrine, theory, and jurisprudence? Does that link between teaching and scholarship apply, however, to teaching law students to be

3. Roy Stuckey et al., Best Practices for Legal Education: A Vision AND A ROAD MAP (2007) [hereinafter Best Practices]. CLEA was incorporated in 1992 with a mission of developing and supporting clinical education as a means of preparing law students and lawyers for more effective legal practice. See Mission, Clinical LEGAL EDUC. Ass'N, http://www.cleaweb.org/mission (last visited Mar. 26, 2013).

4. See Best Practices, supra note 3, at 210.

5. See, e.g., Margaret Martin Barry, Practice Ready: Are We There Yet?, 32 B.C. J.L. \& SoC. JusT. 247 (2012); Earl Martin \& Gerald Hess, Developing a Skills And Professionalism Curriculum--Process And Product, 41 U. TOL. L. REV. 327 (2010); Stephen Gerst \& Gerald Hess, Professional Skills and Values in Legal Education: The GPS Model, 43 VAL. U. L. REV. 513 (2009).

6. Not all law professors agree with this assertion. In her reflections, for example, Professor Jessica Owley writes, "Ask professors why they do research and it seems unlikely that they will identify improving doctrinal teaching as the reason. The academy not only educates students in the classroom but serves to build a body of knowledge." Professor Michelle Bryan Mudd states that the Symposium presented an opportunity "to question the prevailing assumption that scholarship is an act largely separate from our teaching and service." In a Symposium working group he attended, Professor Timothy Iglesias noted that while "everyone expressed . . . that the current relationship [between teaching and scholarship] was in some way fractured, divided or strained. ... We all shared an inchoate hunch that an organic relationship is possible." 
more practice-oriented, and what precisely does that term mean? Should our scholarship examine more regularly the problems that practitioners confront and the contexts in which they arise?

This Article contains the reflections of sixteen law professors on this question of whether the movement toward practiced-oriented teaching in American law schools should have an impact on law school scholarship. ${ }^{7}$ After attending a conference hosted by Pace and Albany Law Schools in the spring of 2011 on "engaged teaching," 8 the participants called for a follow-up symposium on "engaged scholarship," which Pace Law School hosted in the spring of 2012. We invited to both events professors who teach property, land use, environmental, alternative dispute resolution, real estate, and energy law: topics that lend themselves to context-related teaching and scholarship, what some call "experiential education." These fields of law are dynamic, undergoing rapid change in practice, and provide a range of highly practical contexts, often within a short drive of the law school, for

7. This article is based on the deliberations and reflections of law professors who attended the Pace Law School Symposium Practically Grounded: Engaged Scholarship on May 4, 2012. The Symposium's planning committee consisted of Professor, Assistant Dean, and Director, Environmental Law Programs, Pace Law School, Lin Harmon; Elizabeth Burleson, Associate Professor of Law, Pace Law School; Uma Outka, Associate Professor of Law, University of Kansas School of Law; and Keith Hirokawa, Associate Professor, Albany Law School.

8. The articles prepared by the presenters at the May 2011 conference on Practically Grounded: Engaged Teaching are available at Volume 2, Issue 1 (2011) Practically Grounded: Best Practices for Skill Building in Teaching Land Use, Environmental, and Sustainable Development Law Summer 2011, PACE EnVTL. L. ReV., http://digitalcommons.pace.edu/pelroc/vol2/iss1/ (last visited Mar. 26, 2013).

9. See Experience the Future: Inaugural National Symposium on Experiential Education in Law, NORTHEASTERN U. ScH. L., $\mathrm{http} / / / \mathrm{www}$.northeastern.edu/law/pdfs/academics/exp-future-papers/program2012.pdf (last visited Mar. 26, 2013). The conference invited lawyers and professors "to promote a shared vision of legal education that ensures law graduates are ready to practice with the full complement of knowledge, skills, and ethical and social values necessary to serve clients and the public interest, now and in the future." Conferences, NORTHEASTERN U. SCH. L., http://www.northeastern.edu/law/academics/conferences/ (last visited Mar. $26,2013)$. 
exploration in the classroom and in research. ${ }^{10}$ Professors who teach in these areas and labor in these nearby laboratories are capable of responding to the criticism that law schools are not producing graduates with practical experience and that they should reorient their preparation of law students more toward the experiences of lawyers in practice. ${ }^{11}$

The presenting question for the 2012 Symposium was how can engaged scholarship enhance teaching to prepare students for the legal profession and help to solve the critical problems of the day. ${ }^{12}$ The event employed a format designed to discover new ways of thinking about engaged scholarship. Each participant was asked to draft and submit in advance brief reflections on this question. At the Symposium, each professor attended seven breakout sessions held throughout the day. At each of these sessions, one participant presented to a small group of professors for ten minutes on her reflections, pinpointing issues, challenges, and themes involved in engaged

10. For the editor, the investigation into engaged legal education began with a survey of land use law professors conducted with then Albany Law School professor, now Touro Law School dean, Patricia E. Salkin, and the publication with her of Practically Grounded: Convergence of Land Use Law Pedagogy and Best Practices, 60 J. LEGAL Educ. 519 (2011) [hereinafter Practically Grounded]. We found significance evidence that law professors are bringing a dazzling array of practice contexts and learning exercises into the land use class room. See id. at 533-47. That discovery led us to organize the May 2011 conference as a joint venture with Albany Law School and its Center for Excellence in Law Teaching and Pace Law School and its Land Use Law Center. Adding to this impetus was the fact that our article quickly became one of the most frequently downloaded of our collective works on SSRN.

11. See Carrie Menkel-Meadow, The Lawyer as Problem Solver and Third-Party Neutral: Creativity and Non-Partisanship in Lawyering, 72 TEMP. L. REV. 785 (1999).

12. In the Symposium's concluding session, a plenary discussion among the participating professors, there was an animated debate about the primary purpose of engaged scholarship. Two formulations were debated that will help the reader understand some of the differing views contained in the professors' reflections later in this article. The participants could not agree as to whether the proper purpose should be "using engaged legal scholarship to enhance teaching to prepare students for the legal profession and to help solve the critical problems of the day" or "using engaged legal scholarship to help solve the critical problems of the day and to enhance teaching to prepare students for the legal profession." In other words, is the purpose of engaged scholarship to involve professors directly in problem solving or is it to equip students to understand the practical contexts within which they will practice. 
scholarship; the remaining thirty minutes were spent in discussion with the group led by a facilitator. With three roundtables operating for each of these seven periods, twentyone sessions were held, enabling each participant to present and to facilitate a forty minute roundtable. Every participant had an opportunity to engage in a small group with all those participating in the Symposium at some point during the day. The breakout sessions were followed by an hour-long wrap up conversation designed to define and discuss the principal issues that participants should address in their final reflections.

Part II of this article synthesizes the critical issues presented at the Symposium. Part III contains the reflections of the Symposium participants-a group of scholars deeply focused on the question of what, exactly, engaged scholarship means in an era of fundamental change in legal education. In Part IV, we conclude with several themes that we recommend for our colleagues' consideration as they reflect on and move us further toward a clear definition of engaged scholarship.

\section{Issues Presented}

Following the Symposium, we gave the participants an opportunity to revise their reflections and submit them for publication in this article. Most of them accepted this challenge; their names and affiliations are listed in Part III below as their contributions appear in alphabetical order. This brief synthesis of their thoughts integrates and highlights only a few of their responses to the key issues identified. It does not do justice to the sophistication contained in their complete remarks, which the reader is urged to study carefully.

\section{A. Many Methods of Engaging Students}

Related to the purely academic issues raised by the question of engaged scholarship are sobering economic realities. Given the high cost of legal education, the mounting student debt, and dim prospects for jobs, particular attention needs to be paid to how the tuition paid by J.D. students is 
spent. According to the ABA, J.D. students spent about $\$ 3.6$ billion on tuition in $2010 .{ }^{13}$ Of that, it is estimated that about $\$ 575$ million is used to subsidize the production of scholarship, most of which finds its way into law review articles. ${ }^{14}$

These economics suggest that consideration should be paid to the question of whether scholarship engages students, either directly in its production, or indirectly by informing classroom teaching. Students seem to agree. Professor Jonathan Rosenbloom presented the results of a study he conducted for the Symposium which concluded that "students are interested in being more involved with academic scholarship, but do not have the opportunity to do so." ${ }^{15}$ Professor Sean Nolon routinely assigns his students portions of his articles to read; he does this for several reasons including that by "bringing them into the gray areas of inquiry, we can help move students from an expectation of certainty to a respect for nuance. This shift is a necessary one for those interested in solving society's most difficult problems." 16 In his reflections on the Symposium, Professor Michael Burger admits his initial confusion regarding the term "engaged scholarship" and "what specialist or general audiences might an engaged scholar aim to reach ... But as the [Symposium] progressed I realized that I had left out perhaps the most important audience for my scholarshiplaw students. Not student law journal editors, mind you. My students."17

The students of Professor Michelle Bryan Mudd were engaged in an analysis she led of the proposed sale of a municipal water company to a private enterprise, one of the first such transfers in the nation. Students were directly involved, published their legal analysis on a regional blog, and "the players involved adjusted positions and strategies in light

13. Steven R. Smith, What They Don't Teach Law Students: Lawyering, N.Y. TIMES, Nov. 20, 2011, at A1. The support of law schools for scholarship include direct salaries paid to professors, research stipends, reduced teaching loads, and paid sabbaticals, among other incentives, several of which are difficult to identify on budgets or to attribute directly to scholarship. Id.

14. Id.

15. Infra Part III.0.

16. Infra Part III.0.

17. Infra Part III. 
of the legal analysis a student posted on the blog."18 She reports that clinical work for a client on agricultural land preservation, which was presented at a series of public hearings in the state, became a co-authored piece for academic publication. The involved students "consider this work to be among the most powerful learning experiences they had during law school ...."19

That the Symposium participants were exploring new territory was expressed several times. Professor Tim Iglesias wrote poignantly, "Why can't what we care about passionately enough to spend dozens (if not hundreds) of hours learning about, probing, brooding over, and finally reducing to scholarly text find its way into the classroom in pedagogically-fruitful ways? In other words, how can we bring engaged scholarship into the classroom?"20 Professor Jonathan Rosenbloom's strategic observation is that "what students see in academic scholarship during their legal education ultimately becomes the legal profession's external perception of academic scholarship."21

\section{B. Engaged in Theory}

Several professors explored methods of connecting more traditional, theoretical scholarship with teaching and problem solving. As a result of his exploration of multiple intelligence theory, Professor Michael Burger concludes that "creating scenarios in which students can reflect on the ways in which their own values inform their understanding of environmental problems . . . can deepen comprehension of the different value systems that factor into environmental decision making and foster an appreciation for the depth of real-world conflicts." 22 Professor Uma Outka notes that "there are many ways for scholarship to engage critical problems of the day, from practical to doctrinal to cultural to theoretical perspectives and

18. Infra Part III.A.

19. Id.

20. Infra Part III.0.

21. Infra Part III.0.

22. Infra Part III. 
critiques." ${ }^{23}$ Citing Catharine MacKinnon, she would reframe the discourse by asking "not whether scholarship is engaged or not, but with what it is, in fact, engaged."24 She adds that "scholarship that ... influences the trajectory of a legal discourse, that develops our understanding of law and its function, implementation, interrelationships and context, is no less engaged than work focused strictly on problem solving." ${ }^{25}$

Professor Christopher Serkin writes about the deep division in core values that underlie the rancorous public debate about the use of the power of eminent domain. With this and with similar divisions that appear in other property contexts, "the real stakes of the debate often involve deeper normative commitments than are immediately apparent. By making those underlying stakes move obvious, even the most abstract or the most narrow property scholarship can more fully engage the most pressing issues of the day." ${ }^{6}$ These comments effectively dispatch Professor Serkin's concern that "when I read about a turn to engaged scholarship, I cannot help hearing within it a call for more 'practical' scholarship . . . that focuses on topics with more immediate payoff than is found in most of my writing." 27

Professor Nestor Davidson agreed with the thrust of Professor Serkin's reflections by noting that "the dichotomy between seemingly abstract scholarship on the one hand and more immediately 'real-world' concern is not as stark as it might at first seem. Indeed, it is absolutely vital to embrace the intersection between these two approaches." ${ }^{28}$ He continues:

Abstract, theory driven scholarship also engages the "real-world," even if at a different pace and over a different horizon, and the kinds of questions that engage traditional scholars are inevitably generated by law's practical role in

23. Infra Part III.0.

24. Id. (citing Catharine MacKinnon, Engaged Scholarship as a Method and Vocation, 22 YALE J.L. \& FEMINISM 193, 196, 203 (2010)).

25. Infra Part III.0.

26. Infra Part III.0.

27. Id.

28. Infra Part III.0. 
social ordering. Occupying a middle ground between theory and practice is an important part of what we have to offer as legal scholars. ${ }^{29}$

Professor Kalyani Robbins supports these views.

If we were to merely focus on one practical problem after another, solving it in a seemingly reasonable way and continuing to the next, we may be operating blindly in relation to our most fundamental concerns. What would we do without John Locke providing us with one of our most deeply meaningful justifications for government control over the people: that without law there can be no freedom. The relationship between theory and practice is one of mutual dependence. . . Far too often theoretical scholars engage in their theoretical analysis and stop there. . . These scholars could contribute so much more, without sacrificing their theoretical credentials, by simply taking a little time to spin off their theories with a resulting practical proposal. $^{30}$

\section{Countering the Culture}

As a tenure-track clinician, Professor Kim Diana Connolly was "cautioned against writing that was too 'practical' or that garnered attention from agencies or legislators." ${ }^{1}$ Professor Patrick McGinley notes that "traditional legal scholarship emphasizes analysis and deconstruction of legal doctrine-while generally giving short shrift to real world context. . . . The academy must recognize the historic limited impact and influence of traditional legal scholarship ...."32

Professor Owley adds that "there is a divide in the

29. Id.

30. Infra Part III.0.

31. Infra Part III.C.

32. Infra Part III.0. 
academy between skill professors and doctrinal professors." ${ }^{33}$ Professors are "supposed to be one or the other." ${ }^{4}$ Current tenure standards, she notes, "push faculty to write singleauthor theoretical pieces to be published in top twenty general law reviews. Competition for prestige and playing the rankings game reinforces this model even for faculty members who have obtained tenure." 35 That said, she concludes that "thinking critically about what we chose to research and where we choose to publish in terms of what will benefit our students and our community is the first step in creating more engaged scholarship."36

\section{The Virtous Cycle}

To Professor Jill Gross, "scholarship that is 'engaged' means that it is interconnected with the other two pillars of the legal academic: teaching and service." ${ }^{37}$ At the Symposium, she concluded that "my teaching and scholarship are already in a quasi-symbiotic relationship . . . but that my primary obstacle was my own misperception that students simply weren't interested." 38 The stories told at the Symposium suggested to her "many ways in which I could involve students far more in my scholarship, which would then lead to engaged teaching, which would then lead to even more engaged scholarship." 39

Professor Matthew Festa envisions "an interactive cycle where engaged teaching and community involvement can provide us with real-world insights that can contribute to scholarship; and our scholarship-whether focused primarily on theoretical, doctrinal, or practical issues-can in turn enhance teaching outcomes and our potential contributions to real land use issues." 40

Professor Michael Burger discusses how "immersing

33. Infra Part III.0.

34. Id.

35. Id.

36. Id.

37. Infra Part III.0.

38. Id.

39. Id.

40. Infra Part III.0. 
students in the pressing problems of the day" might extend "the professor's own thinking about the issues at hand. This integration of scholarship, skills-oriented teaching, and current events illuminates aspects of scholarship, practice, and teaching that have arguably received less attention than they deserve." 41

\section{E. Reaching the Bar and Beyond}

Reflecting on Chief Justice Roberts's assertion that there is a disconnect between contemporary scholarship and the legal profession, ${ }^{42}$ Professor Keith Hirokawa notes that "scholarship can be presented to a wider variety of audiences." 43 To illustrate, a traditional law review article by Professor Michelle Bryan Mudd on protecting environmental rights under state constitutions, at her students' urging, became the basis for a combined clinical seminar and CLE for practitioners that involved the lawyers and students meeting in small, interactive groups to discuss discrete applications of the paper to state contexts. ${ }^{44}$

Professor Kim Diana Connolly writes about using her lengthier works to create ABA CLE materials that reach practitioners, other methods of spinning off shorter, related works in newsletters, and co-authoring with the head of a nonprofit engaged in problem solving. ${ }^{45}$ Professor Matthew Festa discusses

speaking to nonacademic community, bar, government, or policy groups; writing op-eds or short pieces for nonlawyers on local issues; speaking with the local media; consulting, or serving as an expert witness; blogging, and

41. Infra Part III.

42. Chief Justice John Roberts, Address at the Fourth Circuit Court of Appeals Annual Conference (June 25, 2011) [hereinafter Fourth Circuit Conference], available at http://www.c-span.org/Events/Annual-FourthCircuit-Court-of-Appeals-Conference/10737422476-1/.

43. Infra Part III.

44. Infra Part III.A.

45. Infra Part III.C. 
participating in community groups. Some of these activities have given me great ideas for research and writing, and seeing these ideas in action has improved both my own academic thinking and our classroom experience. ${ }^{46}$

\section{F. Solving the Critical Problems of the Day}

Symposium professors spoke at length about using their scholarship to tackle pressing legal problems, highlighting the role of lawyers as problem-solvers in practice. Professor Lisa Heinzerling strikes a cautionary note in reporting on her scholarship that engaged environmental regulation cost benefit analysis and climate change.

Neither problem is close to solution . . . [and] their failure of solution is part of the reason I would like to move on. . . . If you are not engaged-if you write purely for the sake of writing, with no thought of real-world consequences-then it is harder to know when you have lost the fight. . . . But if you are engaged, if you write in the hopes of seeing a concrete change in the concrete world, then on occasion you will face the harsh reality that your words, no matter how pretty, have not mattered, and things have not changed. And then you need to decide whether to keep at it, or disengage and move on. ${ }^{47}$

At the local scale, Professor Matthew Festa consulted in a nearby city on zoning litigation

which also gave me a good article idea. I also encouraged my students to attend public hearings on a seemingly unrelated land use 
controversy in Houston. Recently, when Houston was considering a new land use ordinance to address the problem, I was able to draw on both the research and the students' experiences to contribute to the public discussion of the proposed ordinance. ${ }^{48}$

Professor Festa concludes "To turn a phrase on its head, we can "write globally, act locally."'49

In the same vein, Professor Jonathan Rosenbloom engages his class in analyzing laws on issues relevant to sustainability and drafting concrete sustainability proposals to be presented to the Des Moines, Iowa City Council. ${ }^{50}$ In this case, the professor engaged the problems of the day, locally, with his students by his side: an experiential learning approach that "provided an opportunity to bridge the gap between student research and real world challenges. It also provided the students with a much better practical understanding of complex issues that could not be explored through a static and isolated learning environment." 51

\section{Reflections of the Symposium Participants}

\section{A. Michelle Bryan Mudd ${ }^{52}$}

Thich Nhat Hanh, a renowned scholar and teacher of Zen Buddhism, uses the concept of "interbeing" to help his students recognize that no part of our planet can exist wholly separate from the other parts of our planet..$^{53}$ For law professors, the concept of interbeing can similarly help us recognize the profound interrelationships among our teaching, scholarship,

48. Infra Part III.0.

49. Id.

50. Infra Part III.0.

51. Id.

52. Associate Professor, Natural Resources \& Environmental Law Program, and Director, Land Use Clinic, University of Montana School of Law.

53. See generally THICH NHAT HANH, INTERBEING: FourteEn GUidELINES FOR ENGAGED BUDDHISM (1987). 
and service. As the legal academy focuses its attention on "best practices" in teaching, there is opportunity to hold a complementary conversation about best practices in scholarship, and to question the prevailing assumption that scholarship is an act largely separate from our teaching and service.

At the Engaged Scholarship Symposium at Pace Law School, participants began such a conversation and some preliminary themes emerged. Among them, a recognition that law schools can do more to teach our students and the general public about the importance of legal scholarship and its role in the law. Additionally, alongside traditional scholarly articles, the legal academy can do more to support new modes of scholarship that directly engage our students and communities. And finally, we as individual professors can be more intentional about bringing our scholarship into the classroom and extending it out to our communities. The Symposium discussion also prompted me to reflect on three of my most rewarding experiences from the past year $\square$ experiences which, in hindsight, I now recognize as those moments where teaching, scholarship, and service aligned most closely for me, my students, and our community.

\section{Supporting a Student Law Blog that Serves the Community}

This first experience highlights the importance of teaching our students about the role of scholarship in society. It also highlights the ways non-traditional modes of publishing can increase the impact of our work. This past fall, one of my water law students wanted to write about the purchase of our city's municipal water supply by an international private equity investment company. Only the fourth such type of purchase in the United States, the sale was controversial and the public was grappling with many questions and concerns. Rather than opting for a traditional legal paper, we decided it would better serve the community for the student to do real-time, online pieces about the Public Service Commission's review of the sale, with me supervising the writing. The result was a blog 
housed on Et Al News ${ }^{54}[$ letalnews.org/missoulawater/ $\square$ an interdisciplinary collaboration between the Schools of Law and Journalism, where students provide legal and factual coverage of environmental proceedings. The blog received viewings in the thousands, and, remarkably, we witnessed that the players involved adjusted positions and strategies in light of the legal analysis the student posted on the blog. When the legal student presented her work to an academic audience this past spring, one of the PSC members attended and took copious notes about the student's recommendations for future review of private equity investment sales.

\section{Presenting Legal Scholarship to Students and the Bar}

This second experience reveals how our legal scholarship can benefit students and practitioners and promote experiential learning. At the Engaged Scholarship Symposium, I discovered that I am not alone in my reluctance to share my scholarship in the classroom. This past spring I overcame that reluctance at the prompting of one of my land use clinic students, who happened upon a recent article I published about protecting environmental rights under state constitutions. The student inquired about whether I would be willing to teach a clinic seminar based on the article. Around the same time, I had begun thinking about ways to better involve environmental lawyers in our program. These questions led to what became a clinic seminar-CLE. In the seminar, I presented my article to both environmental clinic students and environmental lawyers from the community, who received CLE credit for attending. After the presentation, we formed studentlawyer small groups that worked through practice problems. Using factual scenarios inspired by my clinic field work, the small groups applied environmental rights law and then reported their conclusions back to the class. The students loved meeting and talking with lawyers in their field, and the practitioners enjoyed the opportunity to work with our

54. Global Control of Local Water: The Carlyle Group in Missoula, Montana, Et Al: EnvTl. Trial AND L. News, Coverage AND Comment., http://etalnews.org/missoulawater/ (last visited Mar. 29, 2013). 
students. This class has now become a model that we intend to continue in our clinic program.

\section{Transforming Student Service into Engaged Scholarship}

This last experience illustrates how clinical learning can come full circle to scholarship. My clinic students and I spent the last two years creating a report on protecting agricultural lands, and our client asked us to present the report at a series of public meetings. The report's topic is one around which the community is polarized, and the public meetings were packed and rancorous. Through listening to the varying perspectives, however, we were able to go back to the report and make it a more impactful piece. We subsequently received a grant to do further work on the report, and will now adapt the document into a co-authored piece of legal scholarship that can go out into the academic world. The students consider this work to be among the most powerful learning experiences they had during law school, and the community has benefitted from their scholarship and outreach.

These types of experiences are occurring at law schools throughout the country, and I benefitted greatly from the many stories my colleagues shared at the Engaged Scholarship Symposium. At the end of the day, I am left with the firm belief that we should carry on the conversation begun at Pace. Through that conversation, and the sharing of ideas, we are bound to deepen our insight about the interbeing of teaching, scholarship, and service.

\section{B. Michael Burger ${ }^{55}$}

A confession: after a full day of lively roundtable discussions with inspired, talented environmental and land use

55. Associate Professor, Roger Williams University School of Law. The author would like to thank Roger Williams School of Law for the financial support it offers for the development of experiential and skills-oriented teaching methodologies in doctrinal classrooms. The author would also like to thank Peggy Cooper Davis and the past and present members of the Lawyering faculty at New York University School of Law for their dedication to teaching to the whole student, and the whole student body. 
law professors I still am not entirely sure what "engaged scholarship" is, or what it is not. Coming into the Symposium, I was concerned with questions related to content and venuewhat subjects might count as engaged scholarship, what specialist or general audiences might an engaged scholar aim to reach, and how do these choices fit into the professional context of legal academia. But as the day progressed my perspective shifted. I realized I had left out perhaps the most important audience for my scholarship-law students. Not student law journal editors, mind you. My students.

Recent calls for greater emphasis on skills-based or skillsoriented learning in law schools pose a new challenge, and a new set of opportunities, for integrating environmental law scholarship with course design and classroom teaching. Contemporary environmental issues offer an obvious focal point for this integration: in-role simulations and other complex exercises that emerge from a faculty member's academic pursuits can simultaneously develop lawyering skills, engage students in complex analysis of critical problems, and make for an exciting classroom experience for teacher and student alike.

For instance, a professor writing deeply in a specific areasay the regulation of hydrofracturing, the construction of conservation easements, the development of offshore renewable energy, or the evolution of state-level climate change adaptation strategies - could use that expertise to develop a sophisticated simulation or other exercise that requires students to research the law, policy, politics, and procedures, as well as the science, economics, and engineering, in a given scenario, whether it be fictionalized or real-world. Beyond research, the simulation or exercise could also include writing in a variety of forms for a number of different audiences, counseling clients, negotiating with allied and opposing attorneys, making oral and visual presentations, or any of the other skills demanded in environmental and land use law practice. In this way, law professors teaching in doctrinal settings can move toward developing "practice ready" lawyers while immersing students in the pressing problems of the day and even, possibly, extending the professor's own thinking about the issues at hand. 
This integration of scholarship, skills-oriented teaching, and current events illuminates aspects of scholarship, practice, and teaching that have arguably received less attention than they deserve. There are undoubtedly others, but here I will only note two: the role of narrative and rhetoric in environmental law and litigation, and the use of multiple intelligence theory in legal education.

The dynamic relationship between narrative, rhetoric, and environmental law has been the subject of a relatively small universe of legal scholarship. Those articles that have focused on the relationship have, like the far larger universe of political science literature on the topic, analyzed quintessentially environmental stories as a form of political rhetoric. Yet, environmental lawyers and litigators are constantly engaged in telling these environmental stories, and their audiences are not only legislators and media outlets but also opposing attorneys and judges. The narrative construction and rhetorical effect of these stories is not only interesting but also important to understanding how environmental advocacy happens, and ultimately what it is. Thus, it makes for a nice topic for academic analysis, for classroom discussion, and for skillsoriented teaching. After all, one of the things we want to teach law students is how to tell good law stories.

Multiple intelligence theory posits that human intelligence is composed of a number of independent faculties or abilities, each of which entails a set of skills that enable the individual to solve real-world problems. The intelligences include mathematical-logical, linguistic, interpersonal, intrapersonal, musical, spatial, kinesthetic, and moral. The traditional doctrinal classroom targets the logical and linguistic intelligences. An individual's intrapersonal intelligence, however, is a capacity that will have a great impact on a law student's success, both as a student and as a practitioner. This, along with the other psychological intelligences, represents a desirable target for both environmental law scholarship and classroom teaching. In particular, creating scenarios in which students can reflect on the ways in which their own values inform their understanding of environmental problems and the policy choices they would make to solve them can deepen comprehension of the different value systems that factor into 
environmental decision-making and foster an appreciation for the depth of real-world conflicts.

As I noted at the outset, I remain uncertain as to what engaged scholarship is. The evolving standards of the legal academy afford the opportunity to develop scholarship that seeks to engage the professoriate, members of the bench and bar, general readers, and students in the classroom. They also afford the opportunity to develop scholarship and teaching methods that target critical subjects and skills that might otherwise receive less attention, such as storytelling and psychological intelligence. The integration of these notions of subject, audience, advocacy, and teaching, then, presents one starting point for further exploration of what engaged scholarship can be.

\section{Kim Diana Connolly56}

My commitment to "engaged" scholarship led me to the path I chose within the academy-the job of a tenure-track environmental clinician. Among clinicians, countless discussions (both formal ones at conferences and informal ones in venues from listservs to baseball games) focus on what scholarship should involve and how it should be defined. There is a rich "clinical scholarship" world that overlaps some with the "engaged scholarship" literature. Like other clinicians on the tenure track, on my path to tenure I received a lot of advice-including being cautioned against writing that was too "practical" or that garnered attention from agencies or legislators. There were, luckily, others who supported my undertaking research and producing scholarship that "matters"-and their encouragement helped bolster my commitment to "applied" and "useful" research and publication that has captured the attention of some "in the field." Some of my role models have included amazing environmental clinicians who write about vital issues, but many others include non-clinician environmental scholars who write what I would

56. Professor of Law, SUNY Buffalo Law School; Vice Dean for Legal Skills; Director, Clinical Legal Education; Director, Environmental Law Program. 
classify as deeply engaged work.

Those who read this article may engage in some of the reflections I have shared with others, including those who attended the Pace Law School May 2012 Engaged Scholarship Workshop, by asking what exactly is engaged scholarship. I believe it important to the future of legal education that we have broad boundaries as to what is considered scholarship. This dovetails with concepts in William M. Sullivan et al., Educating Lawyers: Preparation for the Profession of Law ${ }^{57}$ and Roy Stuckey et al., Best Practices for Legal Education ${ }^{58}$ that call on us to reconsider our role as educators within the academy. Fundamentally, the issue we are turning to in this exercise is or should be vitally important to each of us: what should the professoriate be about?

My research and scholarly production has involved a number of "engaged" approaches. I have written on "hot topics" as a result of discourse with my practitioner friends; I have produced one article as a direct result of work my students and I did through the Environmental Law Clinic. I have worked on ABA CLE materials that I have then expanded into something that was subsequently published in a law review. I have produced a longer, rigorous article and spun off shorter related works in "newsletter" and other types of settings. I have coauthored with the head of a non-profit. I have considered and adopted other engaged research approaches as well. One of the most challenging parts of such work can be remaining true to the academic analysis process when the advocate within me wants to suppress or redirect certain arguments for the sake of representing the views of my (usually) preferred stakeholders. Then again, in my Environmental Advocacy course I have taught my students that academic work can, absolutely, be advocacy (and still be rigorous and thorough).

I cannot imagine writing and researching without being engaged. This is a trait I believe I share with many environmental scholars, clinical or not. The issues for me are not to get lost in the debate I referenced above ("what is scholarship?") and to determine how best to nurture a range of

57. See generally Educating Lawyers, supra note 2.

58. See generally Best Practices, supra note 3. 
scholarly work that feeds the soul of the researcher, and contributes to the collective good. In my opinion, good scholarship should bring the writer joy and make a difference to someone somewhere. I happen to think that "engaged" scholarship can achieve both of those goals for many on a more frequent and broader level that some other approaches to research.

\section{Nestor Davidson ${ }^{59}$}

This Symposium's quest to reconcile scholarship with a commitment to engagement keeps bringing me back to what I will call Serkin's Anxiety. Not that I worry about Professor Serkin himself. By all appearances he seems remarkably well adjusted and has nothing to worry about as a scholar or teacher by any measure. No, what I mean is the dilemma Serkin has posed in this collection: is the call for engagement in any way a threat to the value of theoretical scholarship?60 I think the answer is no, but more importantly, the dichotomy between seemingly abstract scholarship on the one hand and more immediately real-world concerns is not as stark as it might at first seem. Indeed, it is absolutely vital to embrace the intersection between these two approaches.

I have grappled with this dilemma throughout my career. When I started out as an academic-after several years in the government and private practice-I sought advice from colleagues who had found successful long-term paths through this thicket. A wonderful senior colleague advised me to find satisfaction and meaning in the many different dimensions of what makes up our careers. He cautioned that teaching would be frustrating at times, writing would not always flow, and service could seem overwhelming or, perhaps worse, trivial. The way to make it all work in the long run was to find what is rewarding in each of the various components of what we do, so that if any one dimension felt challenging, as it likely would at some point, the rest could be sustaining.

I took that advice to heart-there is real wisdom in it-but

59. Professor, Fordham Law School.

60. See infra Part III.0. 
it led to a kind of compartmentalization. I generally kept my writing to the more theoretical and abstractly normative variety, ${ }^{61}$ and cordoned off my engagement with the day-to-day work of lawyers and policymakers by getting involved in my local community, serving on the boards of non-profits involved in affordable housing and as a commissioner on my local public housing authority. In a few instances, my scholarship was informed by this engagement, ${ }^{62}$ but by and large, my scholarly interests and my practical experiences seemed to be proceeding on distinct tracks.

I also had the opportunity to take a leave (professionally, although perhaps also of my senses) and spend time in the government, serving in 2009 and 2010 as Deputy General Counsel at the U.S. Department of Housing and Urban Development ("HUD"). When I got to HUD, one of my colleagues there asked me if it was exciting to be able to apply my research in the actual work of a federal agency and I remember thinking, it would be if the connection was at all clear. Instead, my scholarship, which focused on debates about the structure of takings jurisprudence, the psychology of property theory, federalism, and similar issues, seemed largely removed from the kinds of questions of agency authority and the fine-grained details of program implementation that filled my time. I had written about transactional lawyering in affordable housing, but even that seemed mostly to be of interest to other legal scholars. Coming back from my time in government, I similarly found myself at a bit of a loss to find ways to translate that experience into the kind of scholarship that would help illuminate the many serious challenges housing lawyers face today. The gap between the

61. My teaching, perhaps because it affords fairly direct control, is one area that has always felt more integrated to me. I have always tried to incorporate practical problem solving into even the first-year property course I teach, and my upper-level courses always have a fair measure of skills orientation. The best teaching, I firmly believe, helps students understand both why any given area of the law has developed in the way it has, which requires theoretical as well as doctrinal engagement, as well as how and why practicing lawyers approach their work in that area in the way that they do.

62. See, e.g., Nestor M. Davidson, Relational Contracts in the Privatization of Social Welfare: The Case of Housing, 24 YALE L. \& POL'y REV. 263 (2006). 
compartments, each with their own rewards, loomed large.

I have been given the opportunity recently to take a step back and re-think that sense of disconnection. Recently, I moved from the University of Colorado to Fordham Law School, and there is nothing like a lateral move to force introspection about professional identity. What the move has prompted me to understand is that my research, as abstract as it can be, actually does help me be more effective in the policy work I do-to say nothing of my teaching. And the policy work I am engaged in keeps my scholarship grounded, no matter how esoteric the questions I may be exploring. I have found some wonderful moments of serendipity in the mosaic that is traditional scholarship, and as I look back, I see patterns in the work that have allowed me to connect debates that are, in the best sense of the word, "academic," with the work of those engaged more directly in contemporary policy.

I appreciate the value of having a space in our society for reflection and critical thinking that is not directly instrumental, and appreciate Professor Serkin's defense of the importance of scholarship that is not bounded by the art of the immediately possible. My experience, however, suggests an inherent connection across both sides of the seeming divide this Symposium posits. Abstract, theory driven scholarship also engages the "real world," even if at a different pace and over a different horizon, and the kinds of questions that engage traditional scholars are inevitably generated by law's practical role in social ordering. Occupying a middle ground between theory and practice is an important part of what we have to offer as legal scholars (as well as teachers), even if we each choose to emphasize different ends of the spectrum at any given moment. But valuing the ability to bridge that spectrum can, perhaps, help us all sleep a little better at night.

\section{E. Matthew J. Festa ${ }^{63}$}

I will focus on the question of how we can use our scholarship to engage with our own specific local communities. Land use and environmental law are areas that have special

63. Associate Professor of Law, South Texas College of Law. 
importance locally, which provides us and our students with opportunities to contribute to our communities. I envision an interactive cycle where engaged teaching and community involvement can provide us with real-world insights that can contribute to scholarship; and our scholarship-whether focused primarily on theoretical, doctrinal, or practical issuescan then in turn enhance teaching outcomes and our potential contributions to real land use issues.

\section{Land Use in the Local Community}

Land use is unique in its centrality to local affairs. Just about every local issue has a land use component: real estate, housing, transportation, conservation, parks, education, noise, economic development, and so on. Because of its interdisciplinary nature, it involves experts from various fields and policymakers. More importantly, land use issues affect everyone in the community and arouse great passion. Because of all this, engaging in local issues provides us with a great breadth of possibilities for interesting topics for scholarship; in return, we can use our scholarship to make ourselves and our students more effective participants.

\section{Engaged Teaching: Student Involvement}

One of the best opportunities to learn about local issues is in the classroom. Our students often have a keen sense of what is happening in our communities, and as we teach them the relevant legal doctrines, they can adeptly apply them to realworld issues. There are a variety of ways in which we can use our teaching roles to get our students thinking about and involved in local affairs, which in turn gives us insights that can benefit our own scholarship. Some of the teaching methods that have personally helped my own scholarly thinking have included having the students attend and report on planning commission or city council meetings, or other community events; encouraging participation in neighborhood affairs or planning charrettes; assigning "current events" reports on land use issues in local news, or contributions to a class blog; focusing on original independent research papers; and inviting 
guest speakers to discuss local issues in class. This broad exposure to local ideas and issues has been one of the most rewarding aspects of the course for me as well as my students.

\section{Engaged Service: Getting Involved as Scholars}

We can also benefit from our own involvement in local affairs. Doing so can help us improve our scholarship in two ways: it can help us generate ideas for research and writing that have practical importance, and it can help us better understand the way our ideas may work in the real world. One of the pleasant surprises I have had in my first few years of teaching is the realization that there are indeed many opportunities for even a junior scholar to get outside the ivory tower and get involved in local issues, including speaking to nonacademic community, bar, government, or policy groups; writing op-eds or short pieces for nonlawyers on local issues; speaking with the local media; consulting, or serving as an expert witness; blogging; and participating in community groups. Some of these activities have given me great ideas for research and writing, and seeing these ideas in action has improved both my own academic thinking and our classroom experience.

4. Virtuous Cycle: Engaged Teaching, Scholarship, and Practical Service

If our writing is informed by our teaching and our involvement in local issues, then that scholarship-even if it has a primarily theoretical or doctrinal focus-will in turn inform our future efforts to provide "practically grounded" service and ideas that can help our own students and be useful to the practitioners and policymakers in our communities. I can offer a couple of examples of how my own research has both profited from and helped me contribute modestly to discussions of local land use issues. In one, a conversation with a local newspaper reporter about a then-upcoming Texas Supreme Court property rights case generated an article idea, which in turn led to an amicus brief. The case has been an important subject of class discussion, as well as several excellent student 
academic research papers. In the second example, I did some consulting on zoning litigation in a nearby city, which also gave me a good article idea. I also encouraged my students to attend public meetings on a seemingly unrelated land use controversy in Houston. Recently, when Houston was considering a new land use ordinance to address the problem, I was able to draw on both the research and the students' experiences to contribute to the public discussion of the proposed ordinance. These small examples gave me the chance to use engaged scholarship to enhance both teaching and service.

Our contributions can take various forms, but if we get involved in the local land use and environmental issues in our own communities, it can both enhance and then draw from our scholarly research and writing. One way to view the issue presented in this project is to ask how we can contribute practically to solving real issues by offering or using the expertise or insight that we gain from our scholarly research and writing. I suggest that if we focus on the local issues that affect our own communities, there is a broad range of possible ways to use our scholarship to contribute to practical issues, while at the same time helping our students engage more pragmatically with the legal issues that they will soon confront as practitioners and citizens. To turn a phrase on its head, we can "write globally; act locally."

\section{F. Jill I. Gross ${ }^{64}$}

Before the Engaged Scholarship Symposium, I carefully read reflections by participants on what they thought engaged scholarship meant, and what role, if any, it could and should play in the law professor's portfolio of scholarly work. I read with interest those reflections that perceived the concept of "engaged scholarship," and perhaps the Symposium as a whole, as a threat or even attack on those legal scholars who produce what we label as more traditional scholarship. The premise of that perception is the notion that "engaged scholarship" is an antonym for "traditional scholarship." I disagree with that

64. Professor of Law; Director of Legal Skills Director, Investor Rights Clinic, Pace Law School. 
notion wholeheartedly and thus want to reassure the Symposium participants that I do not view a movement towards engaged scholarship as a movement away from other types of scholarship.

I firmly believe, especially after the Symposium, that there is room in the legal academy for a healthy diversity of scholarly approaches and methods. Legal scholarship has many purposes and functions, including (but not limited to) the goals of educating, synthesizing, recommending, criticizing, applauding, studying, summarizing, projecting, researching, predicting, analyzing, and questioning. To extol the virtues of "engaged scholarship" at the expense of, and as a replacement for, "traditional scholarship" fundamentally misses the point.

To me, scholarship that is "engaged" means that it is interconnected with the other two pillars of the legal academy: teaching and service. In particular, I had not previously considered (at least not explicitly) the notion that scholarship should and could inform my teaching and thus help students in their legal education. At the Symposium, I was asked to participate in a simple exercise ${ }^{65}$ : diagram pictorially the relationship my scholarship has with my teaching-both currently (as it stands right now) and ideally (how I would really like it to be). This fascinating exercise revealed to me that my teaching and scholarship are already in a quasisymbiotic relationship. For example, periodically, by following developments in my field of specialty (securities arbitration), I. perceive a legal problem, I blog about that problem and possible solution, ${ }^{66} \mathrm{www}$.indisputably.organd I then convert that blog posting into a larger piece, either a law review article or a bar journal article. I also frequently submit public comment letters on rule change proposals in the securities arbitration arena that must go through the rule-making process, and occasionally I will expand that comment letter into a scholarly piece.

The Symposium exercise also demonstrated to me that I

65. I am indebted to Professor Tim Iglesias for asking our small group that he was leading to embark on this exercise.

66. I am a regular contributor to the ADR Law Professors' Blog. See ADR PRof BLOG, www.indisputably.org (last updated Mar. 29, 2013). 
would like to heighten the interconnectedness of my teaching and scholarship, but that my primary obstacle was my own misperception that students simply were not interested. Despite survey data showing a low level of current engagement between students and professors on scholarly work, the survey also revealed that forty-five percent of law students surveyed had a "high" or "very high" level of interest in becoming more engaged in a professor's research. ${ }^{67}$ Inspiring stories I heard at the Symposium illustrated to me that law students across the country are enthusiastically involved in research with professors, and not just as research assistants. These stories suggested to me many ways in which I could involve students far more in my scholarship, which would then lead to engaged teaching, which would then lead to even more engaged scholarship. The continuous feedback loop I diagrammed as aspirational could become a reality.

After reflecting on the larger themes that emerged from the Symposium, I have concluded that the "Skills and Values" movement is one manifestation of the impulse of modern legal educators to teach our students to be problem-solvers. Lawyers who are problem-solvers are better equipped to engage with the critical problems of our day, both for individual clients and for society as a whole. By engaging with students through not only our teaching but also our diverse scholarship-doctrinal, theoretical, empirical, and clinical (all of which are engaged with the law)-we will better prepare them to serve their clients and the profession as a whole.

\section{G. Lisa Heinzerling 68}

Here is the question I have been turning over in my mind as I reflected on "engaged scholarship": how does one disengage from a specific course of engaged scholarship? Once one is associated with a kind of a cause, in academia and in the broader world, how does one move on to another topic?

67. See infra note 104, Jonathan D. Rosenbloom, Survey of Drake and Albany Law Students Regarding Faculty-Student Scholarship Connections (unpublished manuscript) (on file with author).

68. Professor of Law, Georgetown University Law Center. 
My own dilemma stems from the fact that I have spent most of my academic life on two broad subjects: the use of costbenefit analysis to judge the wisdom of regulatory policy and the use of the law to address the problem of climate change. I have been as "engaged" as I could hope to be in these two areas. I have written about them in books and law reviews, I have taught them in innumerable classes, I have testified about them before Congress, I have litigated over them. My scholarship led to insights in the classroom, my litigation experience led to scholarship, my scholarship informed my testimony. Several years ago, I even went into the government, as a political appointee at EPA, specifically to work on one of the areas (climate change), and wound up overseeing the agency's work in the other area (cost-benefit analysis).

I have been lucky enough, in other words, to live in a seamless professional web, in which my teaching, scholarship, and public service have all happily reinforced and strengthened each other.

But now I am ready to move on to other topics. I feel I have said all I can on cost-benefit analysis, and I have exhausted my small storehouse of insights on climate. Neither problem is close to solution-cost-benefit is now more entrenched than ever in the regulatory apparatus of the federal government, and climate change is a bigger problem than ever-but, strangely and perhaps shamefully, their failure of solution is part of the reason I would like to move on. In the past, I took Cass Sunstein to task for declaring that "the cost-benefit state is here to stay," but now that he is in charge of regulatory policy for the U.S. government, I am less inclined to keep up the fight. And in the past, I took the EPA to task for failing to move quickly and aggressively enough on climate, but now that I've seen, from the inside, the task the agency faces and the lack of will within and without the agency to face up to the task, I am also less inclined to keep up the fight in this domain.

I do not want to be the skunk at the picnic-I deeply admire the engagedness of the scholars contributing reflections to this Symposium-but my own experience does lead me to add a cautionary note to the embrace of engaged teaching and scholarship. If you are not engaged-if you write purely for the sake of writing, with no thought of real-world consequences- 
then it is harder to know when you have lost the fight. There is always something more you could say, something that might turn the scholarly tide in your direction. But if you are engaged, if you write in the hopes of seeing a concrete change in the concrete world, then on occasion you will face the harsh reality that your words, no matter how pretty, have not mattered, and things have not changed. And then you need to decide whether to keep at it, or to disengage and move on.

\section{H. Keith Hirokawa ${ }^{69}$}

During the U.S. Court of Appeals for the 4th Circuit's 77th annual judicial conference, Chief Justice Roberts asserted that there is a "disconnect" between contemporary scholarship and the legal profession. ${ }^{70}$ Roberts said, "Pick up a copy of any law review that you see, and the first article is likely to be, you know, the influence of Immanuel Kant on evidentiary approaches in 18th Century Bulgaria, or something, which I'm sure was of great interest to the academic that wrote it, but isn't of much help to the bar." He later suggested he would have difficulties recalling the last law review article that he had read.

At first, hearing Chief Justice Roberts's statement was heartbreaking. As a law scholar and teacher, I was embarrassed to witness a law school graduate declare that scholarship bears no professional purpose or import. Although Chief Justice Roberts's education preceded my career, I was embarrassed for my part in producing a lawyer who misunderstands the manner in which scholars exchange ideas and explore the themes of justice and law, or how the ideas of law are reproduced through the educational, legislative, and judicial processes. Likewise, I was embarrassed to play a role in certifying the educational achievement of someone who expresses so little regard for deep thinking about the sources and legitimacy of law.

After reflection on Chief Justice Roberts's comments, I found solace in the notion that even Kant fell to caution when

69. Associate Professor, Albany Law School.

70. See Fourth Circuit Conference, supra note 42. 
he realized that the antinomies would not appear as an achievement to everybody ${ }^{71}$. Not all scholarly undertakings engage all audiences. Some legal scholarship is intended to identify ambiguities and tensions in the law and substantiate solutions that resolve the ambiguities. Other scholarship identifies injustices or biases, trends, or alternative paradigms. Some simply informs by summarizing case law or legislation. Each of these types of projects is subject to the charge of being less-than-engaging relative to the expectations of some particular audience.

The problem might be the scholar's idea that law is a deliberative practice. As members of the professional community that engages in this deliberative practice, we read scholarship to ensure that our thinking is analytically proficient and comprehensively coherent. We imbue our own scholarship with insights that improve the substance and process of law. Nonetheless, we can acknowledge that, to some, "much of the scholarship in present-day law review footnotes moves beyond eclectic to outright babbling."72 Lengthy articles "are often worthwhile, but their sheer density may put off some authors-and readers-who are genuinely interested in legal ideas." 73 The recent growth of online companion journals ${ }^{74}$

71. See Keith H. Hirokawa, Some Pragmatic Observations About Radical Critique in Environmental Law, 21 STAN. ENv. L.J. 225, 248-249 (2002).

72. Benjamin Barton, The Emperor of Ocean Park: The Quintessence of Legal Academia, 92 CALIF. L. REv. 585, 597 (2004) (reviewing STEPHeN L. CARTER, THE EMPEROR OF OCEAN PARK (2002)).

73. Mark L. Movsesian, Introduction: A Good Idea, 33 HofsTrA L. REv., 1121,1121 (2005).

74. Some academics are enjoying the access and simplicity of this new forum in converging scholarship with the practice of law. For instance, Scott Dodson wrote that "the medium provided a wonderful opportunity to reach academics, practitioners, and judges, and thereby to enhance the relevance of the academy to those actually in the trenches." Scott Dodson, Online Journal Supplements .- Fizz or Fizzle?, PraWfsBlawg (Feb. 25, 2008), http://prawfsblawg.blogs.com/prawfsblawg/2008/02/online-journal.html.

Mitchell Rubinstein, in contrast, provides a perspective not from the traditional scholarly form but from the blog form, stating: "Clearly, these online journals are incorporating some of the magic that we bloggers try to offer. They provide their readers with timely commentary and are welcome." Mitchell H. Rubinstein, Are On-line Law Review Supplement Valuable??, ADJUNCT LAW PROF BLOG (Feb. 25, 2008), http://lawprofessors.typepad.com/adjunctprofs/2008/02/are-on-line-law.html. 
responds by providing a convenient and accessible outlet for reasonably succinct scholarly analysis. ${ }^{75}$ On the other hand, as Lawrence Solum notes, "[a]rticles should be as long as they need to be-no longer, but no shorter."76

The publication of Best Practices and Educating Lawyers inculpated not just legal education in the classroom, but also in the role of research and scholarship and its relevance to the practicing legal community. However, neither Best Practices ${ }^{77}$ nor Educating Lawyers ${ }^{78}$ has explored whether or to what extent the law review should be targeted in the reform of legal education. In my view, the law review is an integral element of the institution and experience of law school. We should, and can, resist the impulse to transform the purpose of scholarship by speaking only to an audience that wants to receive information without engaging the scholarship. On the other hand, scholarship can be presented to a wider variety of audiences. Yet, I remain uneasy with Chief Justice Roberts's commentary on scholarship. Perhaps the solution is as simple as making sure the law reviews publish Kant-free primers on the law of evidence (U.S. or any other country). However, if such an exercise will be the basis for adjudication, the profession (and the society that law governs) is in trouble.

75. Movsesian, supra note 73 , at 1121-22 (describing the Hofstra Law Review's framework for setting aside a section of each volume for shorter, more practical scholarship, as responding to a "real need in legal scholarship. ... [A] space for brief, but careful, treatments of legal subjects in a medium that readers can readily find and preserve." The work published in this section is then reproduced online in a separate section of Hofstra Law Review's website. Category Archives: Ideas, Hofstra L. REv., http://www.hofstralawreview.org/category/ideas (last updated Sept. 24, 2012)).

76. Lawrence B. Solum, Download It While It's Hot: Open Access and Legal Scholarship, 10 LEWIS \& CLARK L. REV. 841, 854 (2006).

77. See Best Practices, supra note 3.

78. See Educating Lawyers, supra note 2. 
I. Tim Iglesias ${ }^{79}$

\section{The Opportunity Within the Crisis: Integrating Our Scholarship With Our Teaching}

Law schools are in trouble. The legal services market collapsed in the wake of the Great Recession when it was already in the midst of a historic restructuring. Media hits on law schools and legal scholarship-some unwarranted or exaggerated-are still rippling in the news. Meanwhile, the Carnegie $^{80}$ and Best Practices ${ }^{81}$ efforts to reform law teaching are still incompletely established. It would appear to be an odd time to consider improving the lot of a law professor. Yet, this is just such an opportunity. We have the opportunity to integrate our scholarship with our teaching, and to direct both to addressing the critical problems of our time.

"Engaged teaching" means focusing on real problems for practicing lawyers, not just teaching legal doctrines, policy issues, and theoretical problems in the abstract. "Engaged legal scholarship" intends to offer thoughtful and practical ideas for problem-solving that are grounded in careful understanding and analysis of the problem. Most, if not all, law professors are and intend to be "engaged" in their teaching and scholarship in some fashion. It seems the two should fit well together, but often they appear to conflict or to be separate worlds.

In one small group meeting, we took a few moments to express graphically the current relationship between our teaching and scholarship and how we would prefer the relationship to be. Everyone expressed both that the current relationship was in some way fractured, divided, or strained, and the desire for a closer connection between the two. We all shared an inchoate hunch that an organic relationship is possible. As one participant put it: "We want to figure out how to make everything work together better."

79. Professor of Law, University of San Francisco School of Law. Professor Iglesias tries to integrate his commitments to fair housing and affordable housing in his teaching and scholarship.

80. See Educating Lawyers, supra note 2.

81. See Best Practices, supra note 3. 
Every case in a casebook was once a real conflict played out to an intense degree. Why is it that when printed on the page, they so often lose their life? Yet bringing contemporary conflicts into the classroom can seem daunting. Why cannot what we care about passionately enough to spend dozens (if not hundreds) of hours learning about, probing, brooding over, and finally reducing to scholarly text find its way into the classroom in pedagogically-fruitful ways? In other words, how can we bring engaged scholarship into the classroom?

At one level this is a no-brainer. All elements of a law professor's job demand the same set of activities: reading, thinking, listening, writing, and speaking. We can integrate our scholarship and teaching when we are mindful of why we write, what we write, to whom, and where we publish. For this we need a community of like-minded scholars to encourage us in this endeavor. We can assist each other in this venture by helping frame issues for research, suggesting several versions of each project for key audiences, helping place the versions in appropriate venues, and sharing our network of contacts. In these ways we can help each other's scholarship have a life beyond the law review page.

For the teaching side, we need to reach out to practitioners and advocates for ideas, perspective, and accountability. They can help us cut and frame issues to be right-sized for student comprehension. Focusing on the legal problems and tasks that confront working attorneys will often be technical and not sexy, but students will appreciate its authenticity as real legal work. It takes time to provide the necessary context, but our taking the time will teach our students to appreciate its critical importance.

There are no magic formulae-each of us who is attracted to this ideal will pursue integration in our own way. Over time we need to identify and to nurture virtuous circles between our scholarship and teaching, in which each feeds and supports the other. We need to address the numerous obstacles to this pursuit. And we must manage the inevitable tensions between the two, especially time limitations.

If we follow this path, we will be happier and more productive in all aspects of the job. Our students will be better trained and more enthusiastic. And, a side benefit of greater 
integration between our teaching and our scholarship may be that open-minded critics of the legal academy will better appreciate what we do.

\section{J. Patrick C. McGinley ${ }^{82}$}

In my view, understanding and solving the critical legal problems of our time requires examination and study of doctrine, process, procedure, and-importantly-the context in which these problems arise and ultimately are addressed by legislatures, administrative agencies, and the courts.

A major constraint preventing our scholarship from making more significant contributions to understanding and solving extant critical problems is that traditional legal scholarship emphasizes analysis and deconstruction of legal doctrine-while generally giving short shrift to real world context.

To me, engaged scholarship presents the very difficult task of synthesizing the complex context in which discrete legal problems often arise. Whether law school courses are doctrinally or practice-oriented, neither law students, those who teach these courses, nor potential readers of our scholarship can fully understand nor effectively work to solve the critical problems of our time without grasping the core context involved.

It is fundamentally vexing that legal scholarship (including that which is considered, by peer consensus, to contain brilliant, cogent, and detailed strategies for resolving serious societal problems) reaches a limited audience and has limited influence on policymakers or the public. However, the dawn of the age of electronic media strongly points in the direction of a way legal scholarship may evolve to reach and impact a more numerous and diverse audience.

Deserving of discussion and experimentation, then, is how electronic "links" to videos, photographs, and non-legal writing might play a role within legal scholarship to allow better communication of both doctrinal and practical lessons. The goal

82. Charles H. Haden II Professor of Law, West Virginia University College of Law. 
would be to convey ideas inherent in scholarly work to provide a broader, more easily understandable context for grasping underlying legal issues. Supplying broader context, in my view, will significantly inform the judgment of teacher and student alike-whether a course is practice or doctrinally-oriented (or an amalgam of both).

An obstacle to this approach that must be overcome is the ingrained perspective of the hierarchical value of traditional legal scholarship in the academy. A major constraint on the evolution of an enhanced scholarship model as suggested above is likely to be the resistance among law faculties to acceptance of the value of new, media enhanced approaches to legal scholarship. For the better part of the twentieth century, examination of non-tenured law faculty scholarship for promotion and tenure purposes focused on traditional legal scholarship_-primarily the law review article. This is not to say that such articles should be seen as having a lesser value, but rather that there are additional and equally valuable outlets or approaches to legal scholarship that should be highly valued as legal education evolves.

Critical analysis of what we do and what we value as legal scholars is appropriate at a time when the role and goals of legal education are being questioned and heavily criticized by some within and without the legal profession. In my view, for legal scholarship to evolve optimally, traditional law review scholarship should continue to be highly valued. However, the academy and the profession should consider embracing and valuing new media-enhanced integration of context into legal scholarship. Moreover, bias against the distribution/publication of evolving scholarly efforts through new non-law review outlets for scholarship must be examined and modified.

The time has come to take advantage of the opportunities offered by media to meet the challenges of a new age. The academy must recognize the historic limited impact and influence of traditional legal scholarship and identify new media vehicles that will allow legal scholarship to more effectively reach a broader audience. We do not research and prepare scholarship only for ourselves, but to serve the public and advance the rule of law in the broader world. The better real-world context is appreciated by the consumers of our 
scholarship (students, readers, others), the more effective we will be in providing resources that can be utilized in solving the critical problems of the day.

\section{K. John Nolon ${ }^{83}$}

Regarding the regulation of coastal development and many other aspects of climate change management, we have entered a transitional era. Profound conflicts of opinion and lack of scientific certainty make it difficult for existing institutions to solve problems through traditional litigation, regulation, and decision-making processes. The practice of law, administrative decision-making, and the law school curriculum are path dependent, directed by more than thirty years of traditional approaches to problem-solving. In this pivotal moment, these paths will change; agencies are challenged to rethink their strategies, lawyers to rethink their practices, and law professors to rethink what they teach.

This article documents a sea change in the environment and in problem-solving regarding sea level rise and coastal land development. It reports on the innovative institutions and strategies created by agency officials, industry representatives, and their attorneys. Their achievements should inform legal practice, administrative procedures, and legal education. Law schools should be ready given the constant criticism they have endured that calls on them to reorient their teaching toward the experiences of lawyers in practice, particularly those who are practicing at the cutting edge.

Recent criticisms ${ }^{84}$ of legal education urge law schools to change their teaching goals and methods to ensure that law

83. See supra swordnote. These reflections are mostly taken from a recent law review article published by the Brooklyn Law Review and are reproduced here with permission. John R. Nolon, Land Use and Climate Change: Lawyers Negotiating Above Regulation, 78 BRoOK. L. REV. 521 (2013). They are taken from the conclusion of the article and offered as an example of engaged scholarship. Most of the footnotes in this section were notes making internal cross-references and have been deleted with some parenthetical explanations inserted where needed.

84. See Best Practices, supra note 3; Educating Lawyers, supra note 2; TASK Force ON LAW SCHOOLS AND THE PROFESSION, AM. BAR ASS'N, supra note 1 . 
school graduates are ready for practice in the modern era. This article describes contemporary challenges that lawyers face; they differ markedly from the "litigate and regulate" approach to environmental protection that characterized practice in the first three decades of the federal environmental law era. They differ as well from the "advocate and decide" approach to land use board decision-making; here, lawyers practice and professors teach vigorous adjudication in administrative tribunals, such as planning board and zoning boards of appeal, with litigation as the ever-present default.

A key principle of legal education found in Best Practices is that law schools should commit to preparing students to practice law "effectively and responsibly in the contexts they are likely to encounter as new lawyers." 85 Sea level rise may be the cutting edge of climate change; it is a worthy context for exposing law students to the challenges of practice, particularly as the consequences of climate change worsen. For today's students to be prepared, they need to know that the law is not a code of rigid rules, but an organic body that changes with the times, with rapid change expected at times like the present, when existing rules and practices seem inapplicable to emerging disputes and circumstances. ${ }^{86}$

Students need to understand when legal rules work and when they must be revised. Major changes in the legal rules occurred in Pardee (1911), ${ }^{87}$ in Euclid (1926), ${ }^{88}$ and in Massachusetts v. EPA (2007). ${ }^{89}$ What was happening in society at each of these junctures that led the law to strike out on a new path? What role did lawyers play in gathering the facts, identifying the issues, and advocating a new paradigm? Why did the courts abide their pleadings?

85. See Best Practices, supra note 3, at 39.

86. Oona A. Hathaway, Path Dependence in the Law: The Course and Pattern of Legal Change in a Common Law System, 86 IowA L. REV. 601, 60406 (2001). Holmes said: "[I]f we want to know why a rule of law has taken its particular shape, and more or less if we want to know why it exists at all, we go to tradition." Oliver Wendell Holmes, The Path of the Law, 10 HARV. L. REV. 457, 469 (1897). 1911).

87. See Pardee v. Camden Lumber Co., 73 S.E. 82, 83, 85-86 (W. Va.

88. See Vill. of Euclid v. Ambler Realty Co., 272 U.S. 365, 386-88 (1926).

89. See Massachusetts v. EPA, 549 U.S. 497, 498-99 (2007). 
What are the appropriate roles of each level of government and the private sector in problem solving in times of crisis? When progress at the Conference of the Parties to the United Nations Framework Convention on Climate Change ("UNFCCC") at Copenhagen stalled, what could the United States government do to effectively lower carbon emissions? What then occurred after the promise of Waxman-Markey deflated with the collapse of a Congressional solution in KerryBoxer? How did stakeholders avoid the uncertainty of regulations in the Uintah Basin and with respect to setting CAFE standards?

What teaching lessons emerge from the creation and potential impact of the Regional Greenhouse Gas Initiative ("RGGI") ${ }^{90}$ and the Transportation Climate Initiative ("TCI") 91 , both interstate institutions operating largely outside the ambit of federal influence? The states that created them seemed reinvigorated by inept approaches at higher levels and have created wholly new agencies with access to impressive resources that can be used to incentivize local governments to adopt and implement land use plans that greatly reduce energy consumption and carbon emissions. Can government policy at the interstate level work with market forces to shape human settlement patterns to drastically reduce per capita carbon emissions? RGGI and TCI are worthy experiments that merit study and support. What are the advantages and disadvantages of this more devolved approach to action needed to solve such critical problems?

As states move toward a posture of accommodation and retreat from sea level rise, how can the legacy of the total takings doctrine of the Lucas case be reinterpreted ${ }^{92}$ Common law doctrines of nuisance, waste, and public trust can be seen in new light as hard-headed practices of due diligence, real property estates, and judicial precedents combine to shape our understanding of the background principles of state law and

90. See Regional Greenhouse Gas Initiative, http://rggi.org (last visited Mar. 30, 2013).

91. See Transportation \& Climate Initiative, Georgetown Climate CENTER, http://georgetownclimate.org/state-action/transportation-andclimate-initiative (last visited Mar. 30, 2013).

92. See Lucas v. South Carolina Coastal Council, 505 U.S. 1003 (1992). 
legitimate investment-backed expectations. Traditional processes used by administrative boards can be tweaked and supplemented to employ and memorialize the deals that can be struck by contingency bargaining: deals that accommodate uncertainty in ways that regulation cannot.

These questions and observations merit exploration in the law school curriculum. The intersections of the common law, statutory principles, administrative regimes, regulatory takings jurisprudence, transactional practice, administrative adjudication, and intergovernmental policy can be used to teach law students the intricate interconnectedness of the law and legal institutions. With this framework understood, they will graduate from law school ready for the challenges their profession faces. The progress described in this article has created a new regulatory environment: one in which lawyers are learning to operate above regulations and beyond the confines of current practices, using new tools and techniques appropriate to a rapidly changing world.

\section{Sean Nolon ${ }^{93}$}

In adding to the voices of this conversation, this reflection raises the connection between engaged scholarship and how we teach in the classroom. One way to use scholarship to more effectively understand and solve critical problems is to write articles that can be used in our courses. When teaching in our areas of scholarship, we should find a way to bring our ideas into the course and should do so by assigning articles, or at least portions, that serve as the basis for discussing major areas of our course.

As a law student, I found that few if any of my professors assigned their articles for us to read. I am not sure how much

93. Sean F. Nolon is an Associate Professor of Law and the Director of the Dispute Resolution Program at Vermont Law School. Professor Sean Nolon's comments on engaged scholarship are informed by his role on the Executive Committee of the ABA's Legal Education, ADR, and Practical Problem Solving (LEAPS) Task Force. For more information on LEAPS, please visit Legal Educ., ADR AND Prac. Problem Solving (LEAPS) PROJECT, http://leaps.uoregon.edu/http://leaps.uoregon.edu/ (last visited Mar. $30,2013)$. 
this is still the case, but guess that it is still common. Not discussing our scholarship in our courses seems like a lost opportunity for us and the students on many levels.

First, assuming that we are writing in areas that we are passionate about, discussing our ideas with students gives us an opportunity to inspire them by sharing something that we care about.

Second, assuming that our scholarship presents solutions to problems, discussing those solutions and the barriers to implementation offers us an opportunity to integrate problem solving approaches into our instruction.

Third, despite the legal academy's efforts to convey the complexity and nuance inherent in legal theory and practice throughout the course of instruction, I see many law students clinging to the idea that bright-line rules are the norm rather than the exception.

By assigning our scholarship and bringing them into the gray areas of inquiry, we can help move students from an expectation of certainty to a respect for nuance. This shift is a necessary one for those interested in solving society's most difficult problems.

As an example, I use portions of my articles, as well as those of others, to make a range of points in some of the courses I teach. In Environmental Dispute Resolution, I assign excerpts as a way to:

- provide a framework for assessing the integrity of a collaborative process;

- explore the nature of governmental decision-making procedures;

- and, illustrate the full range of dispute resolution processes necessary to deal with complex, polycentric environmental conflicts and disputes.

I find that these readings and discussions provide students with a context that enhances their ability to understand the concepts that are being taught in class. This context also provides a framework that we can return to later in the class when discussing related concepts. I am very interested to hear from the other participants in this Symposium about how 
others use scholarship in the classroom as a way to enhance our students' capacity for problem solving.

\section{Uma Outka $a^{94}$}

Last year, leading sustainability scholar John C. Dernbach published a thought-provoking article that bears on the question at the heart of this Symposium. In The Essential and Growing Role of Legal Education in Achieving Sustainability, ${ }^{95}$ Dernbach writes that "[t]he urgency of the sustainability challenge requires engaged scholarship-writing that provides information, tools, and ideas that policymakers, practicing lawyers, and others can use to address the challenges and opportunities of sustainability." 96 This growing role is evident, he says, in the increasing number of articles, books, and journals on related topics, but also work that interconnects with scholarship, such as increasing numbers of course offerings, symposia and conferences, centers and institutes, that focus on sustainability themes. He sees potential for significant progress toward sustainability stemming from this proliferation of knowledge, perspectives, and educational opportunities in the legal academy-but argues that "law schools, as a whole, need to do a great deal more." 97

Dernbach's read on the role of legal education was encouraging to me because I had been thinking about this set of questions ever since I first contemplated a transition from public interest law practice to academia-could one be removed from the fray and yet still be meaningfully engaged with critical problems? His affirmative perspective is consistent with what I have seen in my short time in the academy in the work of numerous legal scholars who routinely contribute their time and expertise in policy arenas, through as well as apart from, their published scholarship. This goes to the "solving" part of our question, which seems especially important now-the

94. Associate Professor of Law, University of Kansas School of Law.

95. John C. Dernbach, The Essential and Growing Role of Legal Education in Achieving Sustainability, 60 J. LEGAL EduC. 489 (2011).

96. Id. at 508 .

97. $I d$. at 518 . 
pressure on environmentalists is high to do more than say "no" to environmental harm, but to follow it with an answer to the question, "if not this, then what-and how?"

Leading into and following this Symposium, I understand engaged scholarship more broadly. The term "engaged scholarship" seems inevitably to imply an opposing disengaged scholarship, which may make it tempting to normatively define what it means to be "engaged" according to form, approach, audience, or subject matter parameters. Yet the wide-ranging perspectives and approaches expressed at the Symposium recommends against this, underscoring that there are many ways for scholarship to engage critical problems of the day, from practical to doctrinal to cultural to theoretical perspectives and critiques. Catherine MacKinnon calls it a false dichotomy, reframing the discourse by asking "not whether scholarship is engaged or not, but with what is it, in fact, engaged." 98 This reframing shifts the emphasis from mode or style of scholarship to the substantive practical and political issues and questions we engage.

As a new professor, I have considered seriously how one might make the most of the academic vantage point, engaged but largely removed from the center of the action. As general counsel for a non-profit environmental advocacy organization, I was typically tied up with litigation matters or playing mostly defense against environmentally harmful state legislation. Academia creates the opportunity to think synthetically about legal and policy issues in ways that are typically foreclosed to those who are practicing and advocating in the field day to day, if only by the inevitable prioritization of matters warranting attention. It may well be, then, that our best work is of the kind that we could not do in another setting. Here too, Dernbach's work and that of many others has influenced how I value the enterprise of scholarship that focuses on the understanding part of our question-related to but distinct from problem solving. I am still thinking, for example, about J.B. Ruhl's articulation of trends changing the context in which

98. Catherine MacKinnon, Engaged Scholarship as a Method and Vocation, 22 YALE J.L. \& Feminism 193, 196, 203 (2010). 
environmental law operates in the coming decades..$^{99}$ Scholarship that explores such dynamics, that influences the trajectory of a legal discourse, that develops our understanding of law and its function, implementation, interrelationships, and context, is no less engaged than work focused strictly on problem-solving. The same can be said of humanist approaches to environmental studies, which enhance our cultural understanding of environmental issues in vitally important ways without devising prescriptive solutions. Many accomplished legal scholars clearly move seamlessly through numerous modes of scholarship, engaging issues of broad importance.

This underscores what was perhaps the most unifying theme I discerned from the Symposium-a notion of engaged scholarship as grounded by a connection to critical problems. The ongoing dialogue between junior environmental law scholars, not just at the Symposium, demonstrates a strong interest in trying methods to engage students with critical issues intellectually while also building skill capacity for getting involved, whether with negotiation exercises, ordinance writing, analysis of proposed bills, case studies, and the list goes on. For new professors, the climate of collaboration and exchange among junior scholars in environmental law provides support for effective integration of engaged scholarship and teaching.

\section{N. Jessica Owley ${ }^{100}$}

Law schools are growing in number. Law school tuition is increasing. Yet, as we produce more lawyers beginning their legal careers with greater debt than previous generations, the availability of fulfilling employment is dwindling. Law school used to be a safe investment, leading to opportunities for wellpaid jobs. In this model, law firms hired promising graduates and trained them in the practice of law. Now, employers facing economic constraints want to hire graduates that are "practice

99. J.B. Ruhl, Climate Change Adaptation and Structural Transformation of Environmental Law, 40 ENVTL. L. 363 (2010).

100. Associate Professor, SUNY Buffalo Law School. 
ready." Law schools are being called on to do more than teach their students critical thinking. Increasingly, employers are looking for students who have gained skills beyond the vague "learning to think like a lawyer." This has led to a questioning of the law school model and a re-examination of law school curriculum. This push has led many universities to increase the value they put on skills training, including both skills courses and (less commonly) doctrinal classes that incorporate skills training.

A growing recognition of the importance of skills training and engaged teaching, where professors expose students to and involve them with the law in new ways, can and should be accompanied by a re-examination of other aspects of academic life. Specifically, schools should turn to academic scholarship. Students have long been surprised to learn that their professors teach only a few classes each year and spend much of their time doing research and writing. ${ }^{101}$ Few faculty members bring their research into the classroom and students may struggle with connecting a faculty member's role as instructor with her role as a researcher.

What then is the job of a legal academic and what should it be? Students usually assert that their professors' job is to train them to be attorneys. Few faculty members view their role that narrowly, however. This is why we tend to call ourselves "academics" or "professors" and not simply "teachers." Faculty members usually define their job as a three-pronged trident of teaching, scholarship, and service. Pressures of tenure and pursuit of always higher law school rankings lead the scholarship prong to dominate the other two. Why is scholarship so important though? Understanding that may help us to understand why certain types of scholarship have been valued over others and consider whether the current

101. I have often been amused by the fact that students make little distinction amongst their professors based upon the qualities that academics seem to measure each other by. Students do not seem to hold tenure-track faculty in higher regard than adjunct or other teaching faculty. Students are unimpressed by titles and rarely care about the academic reputation of their professor. At least this does not seem to be a factor in course selection, even if it is in some way a factor in school selection. Students want faculty who are skilled at teaching. In fact, they often value adjunct faculty higher because of their work experience. 
mode of academic life should change.

I was genuinely surprised to learn that the justification given for faculty scholarship is that doing research improves one's teaching ability. I embrace the logic that by researching a topic we understand it better and thus are better able to teach others about the topics. We make ourselves experts of our subject areas and thereby obtain authority over the topic. More than simply questioning whether research improves teaching, I think we must ask should it. Ask professors why they do research and it seems unlikely that they will identify improving doctrinal teaching as the reason. The academy not only educates students in the classroom but serves to build a body of knowledge. Academic research should help develop minds as well as improve our understanding of the world around us. Universities are a good place to think deep thoughts about fundamental concepts (e.g., what is property, what duties do we owe one another) as well as practical questions (e.g., what should the electricity component of a green zoning code look like, how might a court interpret section 404 of the Clean Water Act). We can and should support all of these types of research. Our role as professors is not just to our students in the classroom but to the communities we live in, particularly those of us at public institutions or with government grants. We must demonstrate that academic research is not simply a decadent self-indulgence.

One of the major challenges of producing engaged scholarship is about perception. There is a divide in the academy between skill professors and doctrinal professors. First, a professor is supposed to be one or the other. Second, skills professors have a second class citizen status in the eyes of some. Many schools do not have tenure-track skills faculty and often pay skills faculty less. This stigma is often accompanied by low or no expectations of research. This challenge is compounded by pressures related to tenure and school rankings. The current tenure standards push faculty to write single-author theoretical pieces to be published in top twenty general law reviews. Competition for prestige and playing the rankings game reinforces this model even for faculty members who have obtained tenure.

The heightened attention on the need for skills training 
has led to more practical elements in classroom teaching. As we change our classroom experiences, should our research shift as well? In examining our scholarship, we should ask if we are writing about the right things in the right way and disseminating our work in the right way. I do not have the answers to these questions, but I think about them with every project I choose. Thinking critically about what we choose to research and where we choose to publish in terms of what will benefit our students and our community is the first step in creating more engaged scholarship.

\section{O. Kalyani Robbins ${ }^{102}$}

Our task for this Symposium was to reflect on the question of how our scholarship can involve us, our students, and readers more effectively in understanding and solving the critical problems of the day. Although this question was designed to stimulate thought and discussion regarding practical scholarship-scholarship with detailed marching orders directed at those who would be most likely to do the marching-I am inclined to begin by considering the related question: what is the practical value, if any, of theoretical scholarship? And, perhaps before we can get there, what exactly is theoretical scholarship? While criticized as aloof and removed from reality, is theory really deserving of this indictment? I raise these questions not to play devil's advocate, but rather in the hope of bringing together the roles of theory and practice in the spirit of cooperation.

As far as I can tell, there does not exist a theoretical work that is not somehow related to our practical existence. The theory must be about something, and that something exists in the real world. Take Immanuel Kant, for example. One can begin with the abstract notion that humanity is made up of a vast array of individual decision-makers, each acting rationally

102. Associate Professor of Law, University of Akron. B.A., University of California at Berkeley (1995); J.D., Stanford Law School (1999); LL.M., Environmental \& Natural Resources Law, Lewis \& Clark Law School (2008). The author wishes to thank all of her fellow participants in the Engaged Scholarship Symposium for the excellent (and engaging) discussions we had while at Pace Law School last May. 
based on her own day-to-day analyses of what needs to be done (or refrained from), and that these individual analyses may not logically reach the same outcome as a shared analysis might. Continuing with this theory, we reach the notion that we might benefit from a method of universalizing these analyses, available individually to each of the numerous decisionmakers. We begin to get more clearly normative by the time we get to Kant's Categorical Imperative: one's choice of action should be based on an analysis of what would happen if everyone else made the same choice. If the choice still seems right once universalized, it is a good choice. This will often lead to a very different decisional preference than if the decisionmaker did not undertake such an analysis. Clearly up to this point we remain at a theoretical level. But the step to practical application is an easy one to make, such as via specific examples. Indeed, environmentalism is a wonderful context for selecting practical applications for this theory.

Theory is not only born out of the practical world, but it is designed to inform the practical world. We need scholars to think deeply about the issues of our time. If we were to merely focus on one practical problem after another, solving it in a seemingly reasonable way and continuing to the next, we may be operating blindly in relation to our most fundamental concerns. What would we do without John Locke providing us with one of our most deeply meaningful justifications for government control over the people: that without law, there can be no freedom. The relationship between theory and practice is one of mutual dependence. When legal scholars write about complex theoretical issues, they are drawing from the real world in order to gather sticks to build the fire of their theoretical ideas. Theory takes what we are actually doing in the practical world and subjects it to deeper examination. Such examination is essential to giving our actions meaning and value (just as one can see the difference between people who subject themselves to deeper examination and those who do not).

However, the goal of this project in which I share a role is not to defend theory, but to determine how our scholarship can improve our practical world. I would suggest that we keep the theory and begin to make better use of it. Just as theory draws 
from the real world, it also feeds the real world if we choose to partake of it. We need to reduce intellectual waste by making more efficient use of brilliant ideas. Far too often theoretical scholars engage in their theoretical analysis and stop there. Their work is then read by other academics and little use is made of it in the real world. These scholars could contribute so much more, without sacrificing their theoretical credentials, by simply taking a little time to spin off from their theories with a resulting practical proposal. This need not even be in the same publication (indeed, it should not be, if it is to reach the target readership), so the scholar may still publish their purely theoretical work in a preferred law review. Not only would such follow-up works contribute greater value to the real world, but they would also significantly improve our theoretical work itself (just imagine the degree of intellectual honesty required if the theorist knows she will be forced to apply that theory in greater detail and make it really work).

My early scholarship was interdisciplinary, containing both scientific and policy analysis, at an initially abstract level, which then always resulted in a clear practical proposal. Proposed regulatory language, suggested litigation approaches, and ideas for agency policy shifts conclude most of my articles thus far. My current work is more theoretical than that which preceded it, applying federalism theory (and some economic theory) to the biodiversity context and arguing for the value of a cooperative federalism approach. I have presented this (still very early) work several times recently, and people always want to know just exactly how this would be applied in reality. This has led me toward further research into the day-to-day management of wildlife in order to make such a proposal. That said, I have relegated that part to a subsequent article, now calling it a two-part project. I have done this in part because each phase is capable of standing on its own, but also because I see two separate tasks here, with potentially two different audiences. First, I am writing the theoretical analysis and hoping the federalism discussion contributes something valuable to scholarly discourse. Next, I have to prove that I can make it work in reality by designing a plan of action, ideally one that would be useful to those operating in the practical world. 
It is this two-step process that I propose today in the context of my colleagues' broader work promoting more practically-engaged scholarship. At the end of the day, didn't most of us arrive at law school hoping to make the world a better place?

\section{P. Jonathan D. Rosenbloom ${ }^{103}$}

\section{"Survey Says"}

In the spirit of engaged scholarship and with the help of Albany Law School Professor Keith Hirokawa, I submitted an informal survey to second and third year law students at Drake Law School and Albany Law School. ${ }^{104}$ Although there are multiple facets to "engaged scholarship," 105 I designed the survey to illicit student thoughts on engaged scholarship as it relates to the integration of student development into academic scholarship. The hope was that the survey would give some indication of how the students viewed academic scholarship, whether they wanted to be more involved with it, and whether they would change anything about it.

The idea for the survey came from an experiential course I taught this past spring. ${ }^{106}$ In that course, students were divided into three groups. Each group was responsible for drafting a concrete proposal to enhance sustainability in the Des Moines,

103. Associate Professor of Law, Drake University Law School. I would like to thank the attendees at the Engaged Scholarship Symposium. A special thank you goes to John Nolon, Elizabeth Burleson, Uma Outka, and Keith Hirokawa for organizing the Symposium, and for letting me be a part of a wonderful and important educational experience that has helped further my understanding of scholarship and its importance in education.

104. For the complete details of the survey, feel free to contact Professor Rosenbloom at jonathan.rosenbloom@drake.edu.

105. For example Professors Michelle Bryan Mudd and Matthew J. Festa explore the challenges raised in connecting scholarship to problem solving in the community, while Professor Tim Iglesias investigates the challenges raised in connecting scholarship to engaged teaching. This is not to suggest that engaged scholarship has distinct silos, but rather that there are multiple perspectives from which to approach and understand engaged scholarship.

106. The course, Sustainability \& the Law, was taught at Drake Law School in Spring 2011, 2012, and 2013. 
Iowa region. The proposals were drafted for a real client and included an analysis of the existing laws on issues relevant to sustainability. Although we had three different proposals, we worked on those proposals together and presented the proposals to the City Council as a cohesive plan to re-think sustainability in the urban environment.

In this context, the students' scholarship was directly connected to the broader community and the engaged learning happening in the classroom. We applied the lessons learned in the classroom and turned them into thought-provoking memorials of the students' work and how to respond to the challenges we face today. The combination of in-depth legal research and experiential learning provided an opportunity to bridge the gap between student research and real world challenges. It also provided the students with a much better practical understanding of complex issues that could not be explored through a static and isolated learning environment. Based on this experience, I wanted to know whether some of the techniques relevant to engaged scholarship used in the course would have broader student appeal.

The following are highlights from the survey followed by some additional thoughts.

- Fifty-seven percent (124 out of 216) of the students were not working with a professor on some type of research project, including a law review note, course related paper, or as a research assistant.

- Of the ninety-two students working with professors on some type of research, only three students were working with professors as joint authors.

- Seventy-eight percent (160 out of 206) of the students ranked "very high" or "high" the idea that receiving publication credit would encourage them to be more involved with scholarly research. ${ }^{107}$ Receiving publication credit was the highest, followed by receiving research money (seventy-six percent), receiving credit hours

107. This was also made clear by several student comments, such as, "If you provided more joint-authorship opportunities, especially if it's for credit, that would likely get more students involved in academic and legal writing." 
(sixty-seven percent), and having scholarship directed at practical aspects of the law (fifty-eight percent).

- Forty-five percent (ninety-five out of 211) of the students said that they had a "very high" or "high" level of interest in becoming more engaged in a professor's research. Thirty percent of the surveyed students were moderately interested, and twenty-five percent had either low interest or no interest. ${ }^{108}$

- Fifty-two percent of the surveyed students said that reading a professor's research for the course the professor taught "[a]dded to [their] understanding of the course materials," while only six percent found the research "[t]otally irrelevant to the course materials."

- Seventy-three percent of the surveyed students ranked providing practical advice to lawyers as "very high" or "high" as the purpose for academic research and writing. Seventy-one percent of the surveyed students ranked influencing public policy as "very high" and "high" as the purpose for academic research and writing. Forty-nine percent of the students ranked "very high" or "high" exploring theoretical legal norms as the purpose for academic research and writing.

While the survey does not fully address what the students really want or fully understand about academic scholarship, it does begin to indicate that many students are interested in being more involved with academic scholarship, but do not have the opportunity to do so. ${ }^{109}$ The survey also gives a small

108. This split among students was reflected in several comments ranging from "[scholarship helps f]oster closer relationships between professors and students" to:

I find academic writing to be among the most, if not THE most, useless aspect of law school. Professors without experience are a waste of everyone's time. Writing academic articles does nothing to help a student learn about the practice of law, especially when the author has no experience themselves.

See supra notes $67,104$.

109. Numerous students made similar comments to: "[I]t would be a 
glimpse at what soon-to-be practicing lawyers think about what makes ideal scholarship, and whether what we are doing is making the practice of law better. For example, seventythree percent of students believe that scholarship should engage the practice of law and contemporary problems, and students want to be a part of drafting that scholarship. Furthermore, almost all of the students found some value in learning through our scholarship and almost half thought one of the main purposes of scholarship was to explore theoretical notions. But yet, academic scholarship has been criticized for being too theoretical and irrelevant to legal education. ${ }^{110}$

What students see in academic scholarship during their legal education ultimately becomes the legal profession's external perception of academic scholarship. The better we educate and explore new areas in which to engage a greater number of students, the better we may be able to fulfill our objectives in legal education and in our scholarship.

\section{Q. Christopher Serkin ${ }^{111}$}

My thesis, in contrast to some of the other reflections collected here, is that engaged scholarship should take the form of identifying and highlighting the stakes of legal and scholarly debates. Disputes in the property literature often involve opaque normative and political commitments. However, important theoretical disagreements about the nature of property are in fact coded arguments for other issues. An example will focus the intuition.

Eminent domain has received enormous scholarly attention in the property literature since the Supreme Court decided Kelo v. City of New London. ${ }^{112}$ In many cases, however, the battles being waged appear to skirt the core implicationsthe real stakes-of one approach over another. For some

valuable experience to not only do in depth research on a topic, but also the interaction with the professor."

110. For one example of criticism of legal scholarship, see supra Part III discussing Chief Justice John Roberts's thoughts on legal scholarship.

111. Professor of Law, Vanderbilt Law School. My thanks to Gregg Macey for conversations about my thesis.

112. 549 U.S. 469 (2005). 
people, the eminent domain debate is about protecting individual property owners against powerful economic interests. But it also implicates very different concerns. Eminent domain, after all, is fundamentally about the reach of the State's power, and the extent to which private rights trump public interests. The more courts are willing to protect private rights-and the power of private property owners to hold out against the government- the less power the government has to respond to public problems and needs. Proposals to limit eminent domain often reflect a suspicion of government action, while support for Kelo reflects a broad commitment to public responses to complex challenges, economic or otherwise.

In this way, eminent domain implicates and divides people depending on their core interests in property. People who are primarily concerned about the environment, and the ability of the government to protect environmental resources are, in general, deeply skeptical that private rights should stand in the way of government power. But people who believe that property rights are necessary to protect the poor and politically powerless from coercion, or that they are necessary to protect individual liberty, may well advocate limiting eminent domain. Other core interests line up differently still-e.g., basic faith in government competence, the ability of markets to overcome assembly problems, and the like.

These perspectives are admittedly too simplistic by (much more than!) half, and elide enormous subtlety and complexity. Nevertheless, when property scholarship dives deeply into questions about the content of the "public use" requirement, the battle lines are often well established in the field but insufficiently clear to the outside world. A recipe for more "engaged" scholarship calls for grounding such arguments in the context of broader debates and laying bare one's normative precommitments and actual interests, to the extent they are implicated. Notice that this has nothing to do with the topic of scholarly writing, or the mode of analysis. The opportunity for both engaged and disengaged scholarship exists whether the discussion focuses on the most obtuse and theoretical questions about the nature of government, fantastical proposals for compensation with no relationship to current law, or narrow and doctrinal treatments of individual states' statutory 
provisions.

Many of these same kinds of divisions reappear in other property topics as well. Whether the topic is landlord tenant law, the rule against perpetuities, or the emerging issue of judicial takings, the real stakes of the debate often involve deeper normative commitments than are immediately apparent. By making those underlying stakes more obvious, even the most abstract or the most narrow property scholarship can more fully engage the most pressing issues of the day.

To put my proposal to an immediate and practical test, I will try to apply it to this proposal itself. What is motivating my response to this Symposium's call for more engaged scholarship? Answering this question is surprisingly uncomfortable. It risks irking some, and laying bare conflicts that might otherwise be swept under the rug. But, in the spirit of engaged scholarship, I offer the following personal account of the motivations for this very essay.

I find the call for engaged property scholarship to be something of a threat. My writing is often purely theoretical. I am interested in exploring abstract questions about the nature of property, and have not shied away from making proposals that have no grounding in current law. When I read about a turn to engaged scholarship, I cannot help hearing within it a call for more "practical" scholarship that prioritizes doctrine, and that focuses on topics with more immediate payoff than is found in most of my writing. I perceive it as an implicit criticism of much of my own work. My proposal for being clearer about normative commitments is therefore an attempt to thread a needle. My goal is to defend esoteric scholarship against a charge of being disengaged by identifying a characteristic that any kind of scholarship can havescholarship that is clear about its motivations and the stakes.

It may be that I am wrong, and that my own insecurities are what prompt me to read the Symposium topic in this way. But, ultimately, that will only become apparent if I am honest about my own commitments and presuppositions, so that people can respond to the heart of my concern instead of to some coded language about how "normative commitments" can make scholarship engaged. 


\section{Conclusion: Towards Engaged Scholarship}

The tradition of scholarship focused on legal theory is decades old; such scholarship is highly regarded by law review editors and passionately embraced by many of the tenured and tenure-track professors in our nation's law schools. How to value legal scholarship is one of the questions this article raises. The current standard is highly introspective. The Scholarly Impact Scores method, for example, measures whether scholarship provokes the exploration of ideas within the community of legal scholars. ${ }^{113}$ Through this lens, the worth of faculty scholarship is viewed by how often it is cited by other members of law school faculties.

Traditional legal scholarship necessarily engages a central objective of law school teaching, which is to impart an understanding of the law and the legal system to students who must learn legal analysis and to "think like lawyers." On the other hand, the practice-oriented influence of Educating Lawyers and Best Practices has been working on the academy for just five years; law teachers are just now learning how they can better prepare their students to practice law "effectively and responsibly in the contexts they are likely to encounter as new lawyers." 114

The thought that scholarship might engage with practiceoriented teaching is a relatively new one, embryonic enough to warn against putting too fine a point on what it is. At the plenary session of the Symposium, the participants discussed this article and decided that it should be entitled "Towards Engaged Scholarship" and communicate that the definition is very much a work in progress. At that session, we settled on the following themes for continued exploration, and recommend them for our colleagues' further reflection:

113. See Brian Leiter, Top 25 Law Faculties in Scholarly Impact, 20052009 (and Highest Impact Faculty in 13 Areas of Specialization), BRIAN LEITER'S $\mathbf{L}$. $\mathrm{ScH}$. RANKINGS, http://www.leiterrankings.com/faculty/2010_scholarlyimpact.shtml (last updated Mar. 30, 2013).

114. See supra $2-4$ and accompanying text. 
- Valuing engaged scholarship and the scholarship professors already produce

- Examining the current culture of legal scholarship and how it affects the ability to produce engaged scholarship (including tenure and promotion standards)

- Examining the tendency to see scholarship, teaching, and service as separate rather than integrated enterprises

- Exploring the many ways scholarship can inform teaching, including:

- How it can add relevance to everyday life in the classroom;

- How it demonstrates critical thinking and complex reasoning; and

- How it can be integrated into experiential exercises

- Educating students and the greater community about the role and value of scholarship in the law

- Using engaged legal scholarship to raise issues that change the legal conversation

- Using engaged legal scholarship to identify, discover, and advance solutions, and to teach students about those solutions

- Making full use of different kinds of publication formats and venues, and having the administrative support to effectively capitalize on these publication opportunities

- Involving students in the production of scholarship

- Facilitating dialogue across jurisdictions and across disciplines

These themes create a new lens for viewing and evaluating legal scholarship in a time of dynamic change in the academy. This article begins a dialogue on engaged scholarship and concludes with the hope that it will help the legal academy reflect critically on the important roles of law professors as academics and as molders of the careers of their students. 